\title{
Pengaruh Iklim Komunikasi dan Komitmen Organisasi Terhadap Kepuasan Kerja Pegawai Kecamatan XYZ Bekasi
}

\author{
Inge Hutagalung ${ }^{1}$ dan Rajab Ritonga ${ }^{2}$ \\ ${ }^{1}$ Universitas Mercu Buana Jakarta \\ ${ }^{2}$ Universitas Prof. Dr. Moestopo (Beragama) Jakarta
}

\begin{abstract}
ABSTRAK
Iklim organisasi merupakan keadaan di sebuah organisasi, tempat setiap anggotanya saling berinteraksi, membatasi diri, ataupun berinteraksi satu sama lain sehingga dapat meningkatkan kualitas kerja sama dan peningkatan kinerja anggota organisasi. Iklim organisasi yang kondusif akan mendorong para anggota organisasi untuk saling berinteraksi satu sama lain yang dapat meningkatkan komitmen pada organisasi. Komitmen organisasi akan menjadi indikator kepuasan kerja karyawan, bersama efektivitas komunikasi interpersonal yang dilakukan. Di sisi lain, keterbukaan komunikasi dalam sebuah organisasi akan membuat suasana kerja menjadi kondusif dan nyaman. Dengan membiasakan diri untuk berketrampilan komunikasi yang baik di tempat kerja, maka karyawan akan mencapai kepuasan kerja. Dengan demikian, masalah penelitian adalah bagaimana pengaruh integrasi variabel iklim organisasi, komunikasi interpersonal, dan komitmen organisasi terhadap kepuasan kerja. Apakah model integrasi variabel iklim organisasi, komunikasi interpersonal, dan komitmen organisasi bisa menggambarkan pengaruh terhadap kepuasan kerja? Tujuan penelitian ini adalah untuk memperoleh data dan informasi tentang model integrasi pengaruh variabel iklim organisasi, komunikasi interpersonal, dan komitmen organisasi terhadap kepuasan kerja. Adapun paradigma penelitian yang digunakan adalah positivistik sedangkan metode penelitiannya adalah survei. Populasi penelitian ini adalah pegawai negeri sipil di Kecamatan XYZ, Kabupaten Bekasi, Provinsi Jawa Barat. Teknik pengambilan sampel dilakukan secara purposive random sampling. Hasil penelitian membuktikan, variabel iklim organisasi dan variabel komunikasi interpersonal memiliki pengaruh signifikan terhadap kepuasan kerja, sedangkan variabel komitmen organisasi tidak memiliki pengaruh yang signifikan terhadap kepuasan kerja.
\end{abstract}

Kata-kata Kunci: Iklim organisasi; kepuasan kerja; komitmen organisasi; komunikasi interpersonal; model integrasi

\section{Effect of Communication Climate and Organizational Commitment on Employees Satisfaction in XYZ District in Bekasi}

\section{ABSTRACT}

Organizational climate is a condition in an organization, where each member interacts, limits themselves, or interacts with each other so that it can improve the quality of cooperation and improve the performance of members of the organization. In conducive organizational climate will encourage members of the organization to interact with each other that can increase commitment to the organization. Organizational commitment will be an indicator of employee job satisfaction, along with the effectiveness of interpersonal communication carried out. On the other hand, openness of communication within an organization will make the work atmosphere conducive and comfortable. By getting used to good communication skills in the workplace, employees will achieve job satisfaction. Thus, the research problem is how the influence of integration of organizational climate variables, interpersonal communication, and organizational commitment to job satisfaction. Is the integration model of organizational climate variables, interpersonal communication, and organizational commitment able to describe the effect on job satisfaction? The purpose of this study is to obtain data and information about the integration model of the influence of organizational climate variables, interpersonal communication, and organizational commitment to job satisfaction. The research paradigm used is positivistic while the research method is survey. The research population is civil servants in XYZ District, Bekasi Regency, West Java Province. The sampling technique was done by purposive random sampling. The results of the study prove that organizational climate variables and interpersonal communication variables have a significant influence on job satisfaction, while organizational commitment variables do not have a significant effect on job satisfaction.

Keywords: Interpersonal communication; job satisfaction; organizational climate; organizational commitment; model integration

Korespondensi: Dr. Inge Hutagalung, M.Si., Lembaga Penelitian dan Pengabdian kepada Masyarakat/ Program Magister Ilmu Komunikasi Universitas Mercu Buana, Jl. Meruya Selatan No.1, Kembangan Jakarta Barat 11650.Email: inge_hutagalung@umb.ac.id 


\section{PENDAHULUAN}

Organisasi merupakan artificial person sehingga dapat berperilaku seperti manusia dewasa dengan segala aktivitasnya, termasuk dapat melakukan perbuatan perdata: mengikat perjanjian, mengelola aset atau pun melakukan tindakan hukum lainnya untuk menjalankan misi guna mencapai tujuan organisasi. Sebagai artificial person, organisasi digerakkan oleh orang-orang yang mengurusi organisasi tersebut. Mereka bertugas memutar roda organisasi, dan bertanggung jawab atas mati hidupnya organisasi. Maka keberhasilan sebuah organisasi dalam kehidupannya akan ditentukan oleh bagaimana orang-orang di dalamnya saling bekerjasama, dan atau dengan berbagai pihak lain di luar organisasi tersebut.

Pada dasarnya, sebuah organisasi dibentuk oleh sekumpulan orang adalah untuk mencapai visi dan misi orang-orang yang berkumpul itu. Termasukdidalamnyaadalahkantor-kantormilik pemerintah yang didirikan oleh negara untuk memberi pelayanan kepada masyarakat warga negara. Dalam kaitan itu, saat menjalankan roda sebuah organisasi maka sumber daya manusia pengawak organisasi akan berinteraksi satu sama lain di dalam bagian organisasi maupun dengan antarbagian organisasi. Oleh karena itu diperlukan keselarasan dalam komunikasi antarpribadi orang-orang di dalam organisasi ataupun institusi agar komunikasi organisasi berjalan efektif dan efisien demi tercapainya tujuan organisasi. Tanpa itu, mustahil sebuah organisasi bisa berjalan sebagaimana diharapkan oleh para pendiri maupun stakeholder lainnya.

Untuk mencapai keselarasan antarbagian dalam sebuah organisasi, maka sebuah iklim kondusif perlu dibangun dalam organisasi tersebut, yaitu iklim di dalam organisasi yang membuat setiap anggota dapat berinteraksi, menetapkan target kerja, dan pengembangan anggota organisasi. Melalui proses interaksi, para anggota organisasi memeriksa eksistensi kepercayaan, dukungan, atau pun keterbukaan terhadap keputusan-keputusan yang diambil oleh anggota organisasi untuk melaksanakan pekerjaan secara efektif dan kreatif, mengikatkan diri dengan organisasi, meraih kesempatan dalam organisasi secara bersemangat, dan untuk menawarkan gagasan inovatif bagi penyempurnaan organisasi.

Terciptanya iklim organisasi yang positif akan mendorong kepuasan kerja dalam organisasi (Adeniji, 2011; Castro \& Martins, 2010; Putri \& Destiwati, 2017; Susanty, 2012). Selain itu, iklim organisasi yang baik diperlukan untuk membentuk citra sebuah organisasi (Rosilawati, 2014) sehingga organisasi tersebut dapat eksis selama-lamanya sebagaimana diperlihatkan organisasi atau institusi yang memiliki usia ratusan tahun. Hal tersebut juga dapat dilihat pada perusahaan-perusahaan nasional ataupun perusahaan multi nasional yang telah berusia ratusan tahun yang hingga kini tetap eksis dan tumbuh semakin besar.

Tentu saja kepuasan kerja karyawan sebuah organisasi, lembaga, instansi ataupun perusahaan, sifatnya relatif karena kepuasan itu bersifat individu, sehingga tingkat kepuasan antara karyawan yang satu dengan karyawan lainnya berbeda-beda. Bekerja bagi seseorang juga dipengaruhi oleh berbagai pengalaman, latar belakang, lingkungan sosial, dan minat karyawan terhadap bidang pekerjaan yang ditekuninya. Selain itu ada iklim organisasi yang melingkupi instansi atau organisasi tersebut. Iklim organsisasi ini ternyata sangat penting dalam memberi warna bagi kehidupan di dalam sebuah organisasi.

Iklim organisasi yang positif akan mendorong para anggota organisasi untuk saling berinteraksi satu sama lain dan menjalin kerjasama antarbagian dan memperkecil hambatan yang mungkin ada di dalam organisasi tersebut. Iklim organisasi yang baik membuat karyawan di dalam organisasi dapat bekerja dengan tenang dan terbebas dari rasa was-was atau pun diskriminasi saat bertugas, meskipun organisasi juga punya aneka ragam publik dengan kepentingan berbeda (Sanjaya, Irwansyah, \& Alunaza, 2017).

Sementara itu, hubungan interaksi sosial antarsesama karyawan dan atasan melalui komunikasi yang terjalin secara efektif akan menciptakan kepuasan kerja dan menumbuhkan rasa memiliki terhadap organisasi. Rasa memiliki ini sangat penting sebab bisa menghasilkan pengabdian yang tulus dari para pekerjanya. Sebaliknya, komunikasi yang tidak efektif karena masalah pribadi, persaingan antarunit kerja, tidak adanya kesediaan atasan untuk mendengar, memahami dan mengakui pendapat ataupun prestasi karyawan akan memicu timbulnya ketidakpuasan kerja. Bahkan lebih dari itu, dapat memicu terjadinya 
konflik antarpribadi di antara para karyawan, dan karyawan dengan atasan yang pada gilirannya akan dapat berdampak pada kinerja atau pun citra organisasi. Persoalan seperti itu bahkan tidak jarang membuat sebuah organisasi menjadi tidak berdaya, tidak mampu berprestasi, atau lebih dari berstatus "antara ada dan tiada" hingga dibubarkan oleh para pengurusnya.

Kajian-kajian terhadap organisasi selalu menarik minat para peneliti untuk memahami apa dan bagaimana perilaku organisasi, atau untuk mencari tahu pemecahan berbagai persoalan yang dihadapi sebuah organiasasi. Sebab, seperti manusia hidup yang selalu dihadapkan pada berbagai persoalan, maka organisasi juga seperti tidak pernah sepi dari berbagai persoalan hidup. Selalu ada masalah yang muncul yang harus dicarikan jalan keluarnya. Atau pengurus harus menjalankan berbagai upaya, cara, strategi dan taktik untuk mencapai visi misi organisasi mereka. Bisa disebut, salah satu kunci keberhasilan sebuah organisasi terletak pada aspek komunikasi pengelola dalam menjalankan aktivitas organisasi.

Penelitian-penelitian yang dilakukan oleh para scholars dalam berbagai kesempatan juga telah berhasil membuktikan bahwa komunikasi interpersonal memiliki hubungan positif dengan kepuasan kerja para karyawan (Irawan \& Venus, 2016; Gusliza, 2013; Qofiki, Sunuharjo, \& Ruhana, 2016; Diasmoro, 2016). Penelitian tersebut membuktikan bahwa komunikasi interpersonal ternyata memiliki hubungan yang positif dengan kepuasan kerja.

Sementara itu, penelitian lain juga menunjukkan adanya hubungan positif antara komitmen terhadap organisasi dengan kepuasan kerja (Natarajan, 2011). Ada hubungan antara komitmen karyawan terhadap organisasi dengan tingkat kepuasan kerja yang dicapai. Komitmen yang tinggi terhadap perusahaan cenderung membuat karyawan memiliki niat yang rendah untuk berhenti bekerja. Komitmen yang tinggi pada organisasi tersebut juga membuat karyawan mendapatkan kenyamanan dalam bekerja dan menumbuhkan minat untuk mengabdi sebagai karyawan dengan sebaikbaiknya. Dengan begitu, komitmen merupakan elemen penting dalam pencapaian kepuasan kerja dalam sebuah organisasi.

Penelitian yang dilakukan oleh Pratiwi dan rekan-rekannya, memperlihatkan bahwa komitmen karyawan terhadap organisasi memiliki hubungan terhadap keefektifan komunikasi interpersonal yang dilakukan. Keefektifan dalam proses komunikasi interpersonal membuat terciptanya kenyamanan dalam situasi kerja. Sebaliknya, jika proses komunikasi tidak terwujud secara efektif maka akan menimbulkan ketidaknyamanan dalam bekerja yang dapat berakibat pada komitmen kerja serta penurunan produktivitas kerja (Pratiwi, Dida, \& Sjafirah, 2018). Dalam beberapa kasus ditemui fakta dan data bahwa ketidaknyamanan dalam bekerja membuat kinerja organisasi terganggu sehingga dapat merugikan pihak lain yang berhubungan dengan organisasi tersebut.

Menyadari bahwa kajian terdahulu telah menggambarkan pengaruh yang ada diantara iklim organisasi, komunikasi interpersonal, komitmen organisasi terhadap kepuasan kerja maka sesungguhnya menarik untuk melakukan penelitian pada variabel-variabel yang telah diteliti secara terpisah untuk diuji secara bersama dalam sebuah model penelitian. Dasar pemikiran untuk melakukan penelitian dalam satu model didasari pada pemikiran bahwa kepuasan kerja harus dipahami secara menyeluruh (holistik) sebagai respons terhadap berbagai aspek pekerjaan baik yang muncul dari diri pribadi (personal) maupun akibat interaksi sosial yang ditimbulkannya (Perloff, 2017).

Dengan mengacu pada berbagai uraian sebagaimana disebutkan di atas, maka masalah (problem statement) pada penelitian ini secara umum adalah: "Bagaimana pengaruh integrasi variabel iklim organisasi, komunikasi interpersonal, dan komitmen organisasi terhadap kepuasan kerja para karyawan yang bertugas di Kecamatan XYZ". Masalah lainnya ialah: "Apakah model integrasi variabel iklim organisasi, komunikasi interpersonal, dan komitmen organisasi bisa menggambarkan pengaruh terhadap kepuasan kerja para karyawan yang bertugas di Kecamatan XYZ, Kabupaten Bekasi?".

Sementara itu, ada pun tujuan penelitian yang dilaksanakan pada awal tahun 2018 ini adalah untuk memperoleh data dan informasi tentang model integrasi pengaruh variabel iklim organisasi, komunikasi interpersonal, dan komitmen organisasi terhadap kepuasan kerja di kalangan pegawai negeri sipil (disebut juga sebagai aparatur sipil negara) yang 
bertugas di Kecamatan XYZ, Kabupaten Bekasi, Jawa Barat. Kecamatan itu dipilih untuk menjadi objek penelitian karena sebagai instansi pemerintah tingkat bawah, unit kerja kecamatan berperan penting dalam memberi pelayanan kepada masyarakat Kecamatan XYZ yang setiap hari silih berganti datang ke sana untuk berbagai urusan adminstrasi mau pun untuk urusan perdata. Bila para pegawai negeri yang bekerja di kecamatan tersebut merasa puas terhadap pekerjaan yang mereka kerjakan, yang berarti mereka juga mencintai pekerjaan itu, maka diharapkan pelayanan yang mereka berikan kepada masyarakat juga akan lebih baik sebagaimana diharapkan oleh warga negara yang sudah membayar pajak. Berbagai keluhan terhadap pelayanan umum yang diterima khalayak saat berurusan degan kantorkantor pemerintah, menjadi salah satu alasan bagi peneliti untuk memilih kantor kecamatan sebagai objek penelitian.

Alasan lainnya, selalu menarik untuk meneliti berbagai perspektif menyangkut pegawai negeri sipil yang jumlahnya di tahun 2016 sudah mencapai 4.374.349 orang berdasarkan data Badan Pusat Statistik. Jumlah aparatur sipil negara tersebut belum termasuk seluruh prajurit Tentara Nasional Indonesia (TNI) dan semua anggota Kepolisian Negara Republik Indonesia (Polri) (BPS, 2017).

Pegawai negeri yang kini dikenal dengan sebutan aparatur sipil negara, merupakan "abdi rakyat" dengan tugas memberi pelayanan umum terhadap masyarakat yang memerlukannya. Para pegawai itu bekerja di berbagai unit kerja kantor-kantor pemerintah yang tersebar di seluruh penjuru tanah air, mulai dari strata terbawah di desa, kelurahan, kecamatan, kabupaten/kota, provinsi, hingga kantor-kantor kementerian/lembaga di ibukota negara serta di luar negeri.

Penelitian menyangkut kepuasan kerja yang dilakukan terhadap para karyawan atau pun pegawai, sesungguhnya bukan lah hal baru. Studi seperti itu sudah banyak dilakukan para scholars yang mendalami permasalahan sumber daya manusia. Namun umumnya penelitian tersebut dilaksanakan di kantor-kantor swasta atau pun perusahaan swasta. Hanya segelintir yang melakukannya pada kantor-kantor atau pun instansi pemerintah atau pun perusahaan milik negara (Badan Usaha Milik Negara BUMN). Dengan alasan seperti itu, maka studi ini memilih unit kerja kantor pemerintah sebagai objek penelitiannya.

Sementara itu, kecamatan sebagai salah satu kantor instansi pemerintah yang mempekerjakan pegawai negeri sipil menjadi pilihan untuk studi ini, sebab instansi tersebut berperan penting dalam kehidupan masyarakat di desa. Untuk memahami tugas pokok dan fungsi seorang camat, dapat ditelusuri pada Peraturan Pemerintah No. 19 Tahun 2008 tentang Kecamatan. Disebutkan, camat bertugas mengkoordinir: (1) kegiatan pemberdayaan masyarakat, (2) upaya penyelenggaraan keamanan dan ketertiban umum; (3) penerapan dan penegakkan peraturan perundangundangan; (4) pemeliharaan prasarana dan fasilitas pelayanan umum; (5) penyelenggaraan kegiatan pemerintahan tingkat kecamatan; (6) penyelenggaraan pemerintahan desa dan/atau kelurahan; (7) serta melaksanakan pelayanan masyarakat yang menjadi ruang lingkup tugasnya.

Dengan melihat tugas pokok dan fungsi camat tersebut maka studi ini mempunyai signifikansi teoritis maupun praktis bagi ilmu komunikasi terutama untuk memahami kepuasan kerja para pegawai negeri sipil yang bekerja di kantor kantor kecamatan. Jumlah kecamatan di seluruh Indonesia sangat banyak. Berdasarkan data dari Peraturan Menteri Dalam Negeri No. 137 Tahun 2017 ada sebanyak 7.094 kecamatan yang tersebar di 416 kabupaten dan 98 kota di seluruh Indonesia. Namun perlu ditekankan di sini, studi yang dilakukan ini tidak mewakili seluruh 7.094 kecamatan tersebut. Studi ini hanya berlaku pada Kecamatan XYX, Kabupaten Bekasi, Provinsi Jawa Barat.

Ada pun alasan pemilihan kecamatan sebagai objek studi didasarkan pada, ruang lingkup tugas seorang camat cukup stategis dalam membina kehidupan sosial, ekonomi, keamanan dan ketertiban masyarakat di tingkat kecamatan. Oleh sebab alasan itu, maka para pegawai negeri sipil yang bertugas di kantor kecamatan dalam menjalankan fungsi staf dalam membantu camat menjalankan tugasnya, menjadi relevan untuk diteliti tentang tingkat kepuasan kerja mereka bekerja di kantor kecamatan. Dalam hal penelitian ini, sebagaimana disebutkan, dilakukan di kantor Kecamatan XYZ, Kabupaten Bekasi, Provinsi Jawa Barat.

Asumsi yang dibangun adalah, keberhasilan 
seorang camat dalam memimpin sebuah wilayah kecamatan, tentu saja tidak dapat dilepaskan dari dukungan para staf dan para pegawainya yang bekerja di kantor kecamatan tersebut. Dengan alasan seperti itulah maka dipandang penting untuk meneliti kepuasan kerja para pegawai negeri sipil di Kecamatan XYZ yang secara langsung telah mendorong peningkatan kinerja kantor kecamatan tersebut. Hal ini penting dilakukan mengingat Kecamatan XYZ berada di daerah industri yang sedang tumbuh pesat, sehingga banyak pihak yang memerlukan pelayanan umum dari kantor kecamatan itu.

Dalam melakukan penelitian ini, ilmu komunikasi digunakan sebagai alat untuk berkomunikasi dalam organisasi dan berinteraksi antarkaryawan. Ilmu komunikasi merupakan ilmu multidisiplin sehingga fenomena komunikasi dapat dipahami dari berbagai perspektif disiplin ilmu. Teori teori komunikasi juga banyak menggunakan pendekatan dari berbagai disiplin ilmu lain. Everett M. Rogers dalam buku yang dia tulis tahun 1994 dengan judul A History of Communication menyatakan pengaruh ilmu komunikasi terjadi ketika ahli ahli sosial dari berbagai disiplin ilmu melakukan penelitian atas masalah komunikasi. Salah satu disiplin ilmu yang banyak memberikan pengaruh dan digunakan pada teori-teori komunikasi adalah ilmu psikologi, sosiologi, ilmu ekonomi, dan ilmu-ilmu sosial lainnya.

Sementara itu, dalam kajian tentang model integrasi pengaruh variabel iklim organisasi, komunikasi interpersonal, dan komitmen organisasi terhadap kepuasan kerja karyawan, secara teoritis diharapkan akan melengkapi pemikiran para ahli komunikasi, sebagaimana telah disampaikan sebelumnya, bahwa komunikasi dipengaruhi oleh disiplin ilmu lain. Sebaliknya, ilmu komunikasi juga mempengaruhi disiplin ilmu lainnya. Dalam penelitian ini, saling keterpengaruhan itu secara spesifik adalah pengaruh ilmu komunikasi terhadap ilmu ekonomi, dan atau pun sebaliknya.

Penelitian ini sebagaimana telah diuraikan dalam metode, adalah menggunakan pendekatan iklim organisasi. Iklim organisasi adalah sifat lingkungan kerja atau lingkungan psikologis dalam organisasi yang dirasakan oleh karyawan sebagai anggota organisasi (Harivarman, 2017). Iklim organisasi dapat memengaruhi sikap dan perilaku karyawan terhadap pekerjaannya. Untuk pengukuran variabel iklim organisasi digunakan empat dimensi, yaitu (1) komformitas, (2) penghargaan, (3) kejelasan organisasi, dan (4) kepemimpinan.

Sementara itu, perlu disadari bahwa sebagian besar kegiatan komunikasi yang dilakukan dalam segala kegiatan, berlangsung dengan menggunakan komunikasi interpersonal yang dapat berubah dari sangat efektif ke sangat tidak efektif. Dalam kaitan itu, penelitian ini menggunakan pemahaman komunikasi interpersonal untuk mempelajari karakteristik efektivitas komunikasi interpersonal. Untuk pengukuran variabel komunikasi interpersonal digunakan lima dimensi yaitu: (1) perspektif yang menekankan keterbukaan, (2) empati, (3) perilaku suportif, (4) perilaku positif, dan (5) kesetaraan. Adanya dimensi dimensi perspektif komunikasi interpersonal dalam dunia kerja, akan membuat karyawan dapat berkomunikasi secara efektif.

Penelitian ini menggunakan pendekatan komitmen organisasi sebagai komitmen afektif, komitmen behavioral sebagai komitmen berkesinambungan, dan komitmen normatif. Pengukuran variabel komitmen organisasi menggunakan tiga dimensi yaitu (1) komitmen afektif (affective commitment), (2) komitmen berkesinambungan atau rasional (continuance commitment), dan (3) komitmen normatif (normative commitment).

Pada sisi lain, penelitian ini menggunakan pendekatan kepuasan kerja yang merupakan bentuk respon karyawan terhadap kondisi lingkungan pekerjaan. Untuk pengukuran variabel kepuasan kerja digunakan lima dimensi: yaitu (1) ketertarikan pada pekerjaan yang dilakukan, (2) kompensasi yang diterima, (3) promosi jabatan, (4) kemampuan atasan dalam memberikan bantuan teknis, dan (5) dukungan rekan sekerja. Adapun model teoritik yang digunakan adalah seperti ditampilkan pada Gambar 1.

Hipotesis penelitian yang dibuat ada tujuh meliputi variabel iklim organisasi, komunikasi interpersonal, komitmen organisasi. Selengkapnya hipotesis itu adalah sebagai berikut: (1) H1: Iklim organisasi berpengaruh terhadap komunikasi interpersonal; (2) $\mathrm{H} 2$ : Iklim organisasi berpengaruh terhadap komitmen organisasi; (3) H3: Iklim organisasi berpengaruh terhadap kepuasan kerja; (4) H4: Komunikasi interpersonal berpengaruh terhadap 


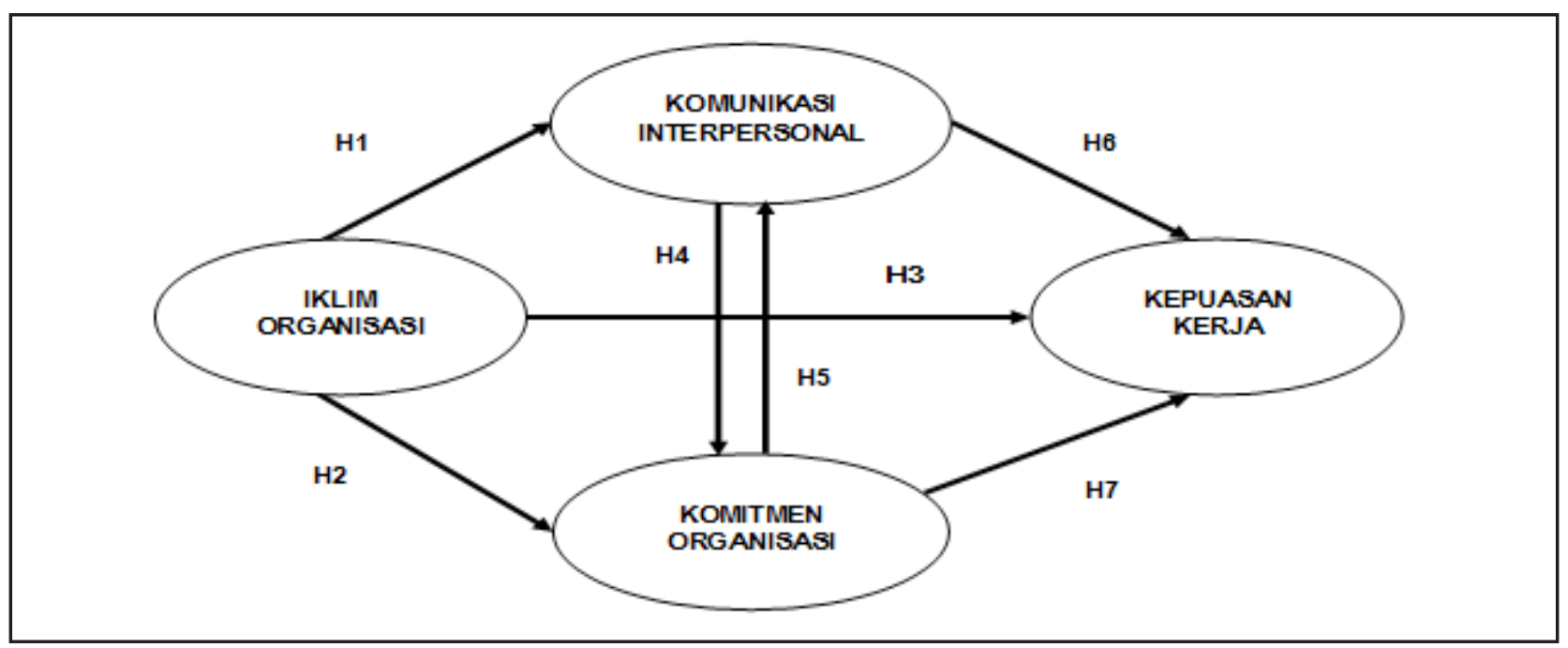

Sumber: Data Penelitian, 2017

\section{Gambar 1 Model Integrasi Pengaruh Variabel Iklim Organisasi, Komunikasi Interpersonal, dan Komitmen Organisasi terhadap Kepuasan Kerja}

komitmen organisasi; (5) H5: Komitmen organisasi berpengaruh terhadap komunikasi interpersonal; (6) H6: Komunikasi interpersonal berpengaruh terhadap kepuasan kerja, dan (7) H7: Komitmen organisasi berpengaruh terhadap kepuasan kerja.

\section{METODE PENELITIAN}

Studi ini menggunakan paradigma positivistik dengan asumsi bahwa terdapat suatu realitas sosial yang objektif di luar sana. Berdasarkan asumsi yang dimiliki, penelitian positivistik, dikenal juga sebagai paradigma klasik, dilakukan guna mendapatkan knowledge atas suatu realitas sosial yang telah terbukti sebelumnya. Pada posisi seperti itu, peneliti menjaga jarak terhadap objek yang hendak dibahas, serta menghindari adanya interaksi antara subjektivitas peneliti dengan objek yang diteliti. Sebagaimana umumnya penelitian pada tradisi positivistik atau klasik, maka penelitian ini berangkat dari metode hipotesis deduktif. Metode ini melibatkan uji hipotesa dengan mendeduksinya dari hipotesa lain dengan tingkat perumusan konseptualnya yang lebih luas.

Pada penelitian ini digunakan metode survei kepada karyawan yang bekerja di Kecamatan XYZ. Argumentasi yang dapat diberikan oleh peneliti terhadap pilihan menggunakan metode survei tersebut, adalah: (1) dengan survei, peneliti memiliki keleluasaan dalam menguji beberapa variabel untuk memahami hubungan antarvariabel yang mempengaruhi kepuasan kerja pada model teoritis; (2) dengan melakukan survei, peneliti juga leluasa dalam menguji model-model teoritis yang ada pada penelitian ini.

Populasi dalam penelitian ini adalah pegawai negeri sipil (aparatur sipil negara) di Kecamatan XYZ, Kabupaten Bekasi, Provinsi Jawa Barat. Metode pengambilan sampel dilakukan secara purposive random sampling. Responden berjumlah 100 orang terdiri dari laki-laki dan perempuan yang merupakan pegawai tetap dan pegawai honorer kecamatan.

Dalam pengujian instrumen, analisis validitas dan realibitasnya menggunakan program komputer "Lisrel 8,80". Adapun teknik yang digunakan adalah analisa faktor konfirmatori (confirmatory factor analysis). Analisis faktor konfirmatori adalah analisis di mana butir butir yang diperkirakan dapat menjadi variabel terukur dari suatu variabel laten tertentu sudah disusun terlebih dahulu.

Dalam melaksanakan uji hipotesa pada penelitian ini, dilaksanakan melalui beberapa tahapan yakni, pertama, tahap analisa data dengan menguraikan data variabel penelitian. Setelah itu, langkah kedua adalah melaksanakan uji persyaratan analisa, dan pengujian hipotesa. Dilanjutkan dengan menguraikan variabel yang meliputi data statistik berupa rata-rata, modus, median, varian, standar deviasi, range, skor maksimal, dan skor minimal.

Langkah berikutnya adalah melakukan analisas inferensial untuk menguji hipotesa penelitan yang dalam hal ini dilaksanakan melalui pendekatan structural equation 
modeling.

\section{HASIL DAN PEMBAHASAN}

Pada studi ini, dilakukan pengujian model integrasi iklim organisasi, komitmen organisasi, dan komunikasi interpersonal terhadap kepuasan kerja para karyawan yang bekerja di kantor Kecamatan XYZ. Sementara itu, apakah model yang ada benar benar cocok dengan data yang tersedia, akan diperlihatkan hasil penelitian dan pengolahan analisa data yang melingkupi analisis inferensial.

Analisis inferensial yang dipakai pada penelitian ini adalah berupa pengujian hipotesa yang meliputi uji kecocokan model, uji model pengukuran (measurement model), dan uji model struktural (structural model). Uji kecocokan model dilaksanakan demi menguji model teoritik, untuk memastikan apakah model sudah compatible dengan data yang tersedia. Kemudian dilakukan dengan uji kecocokan model (goodness of fit) yang juga dipakai dalam menguji model secara keseluruhan. Untuk selengkapnya ukuran kecocokan model tersebut dapat dilihat pada tabel 1 .

Dari hasil uji kecocokan model (lihat tabel 1) memperlihatkan bahwa dari 16 ukuran kecocokan model ada lima ukuran menunjukkan hasil yang kurang baik, enam ukuran menunjukkan hasil yang baik, dan hasil yang relatif dari lima ukuran. Hasil uji model kecocokan ini menggambarkan model teoritik yang kurang sesuai dengan data penelitian.

Sebagaimana telah diuraikan sebelumnya, pengujian hipotesis ini akan meliputi pengujian

Tabel 1 Ukuran Kecocokan Model

\begin{tabular}{|c|c|c|c|}
\hline Ukuran GOF & Target-Tingkat Kecocokan & $\begin{array}{l}\text { Hasil } \\
\text { Estimasi }\end{array}$ & $\begin{array}{l}\text { Tingkat } \\
\text { Kecocokan }\end{array}$ \\
\hline Chi-Square & Semakin kecil semakin baik & 435.54 & Relative \\
\hline Probability ( $\mathrm{p}$ value) & P-value $\geq 0.05$ & 0.00 & Relative \\
\hline NCP Interval & Semakin kecil semakin baik & 47.68 & Relative \\
\hline RMSEA & $\begin{array}{l}\text { RMSEA } \leq 0.08(\text { good fit }) \\
\text { RMSEA } \leq 0.05(\text { close } f i t)\end{array}$ & 0.12 & Relative \\
\hline ECVI & Nilai model mendekati nilai saturated ECVI & 14.54 & Good \\
\hline AIC & Nilai model mendekati nilai saturated AIC & 1439.46 & Good \\
\hline CAIC & Nilai model mendekati nilai saturated CAIC & 1717.06 & Good \\
\hline NFI & $\begin{array}{l}\mathrm{NFI} \geq 0.90(\text { good fit }) \\
0.80 \leq \mathrm{NFI} \leq 0.90(\text { good fit })\end{array}$ & 0.09 & Marginal \\
\hline NNFI & $\begin{array}{l}\mathrm{NNFI} \geq 0.90(\text { good fit }) \\
0.80 \leq \mathrm{NNFI} \leq 0.90(\text { good fit })\end{array}$ & 0.36 & Marginal \\
\hline CFI & $\begin{array}{l}\text { CFI } \geq 0.90(\text { good fit }) \\
0.80 \leq \mathrm{CFI} \leq 0.90(\text { good fit })\end{array}$ & 0.0 & Marginal \\
\hline IFI & $\begin{array}{l}\mathrm{IFI} \geq 0.90(\text { good fit }) \\
0.80 \leq \mathrm{IFI} \leq 0.90(\text { good } \mathrm{fit})\end{array}$ & 0.18 & Marginal \\
\hline RFI & $\begin{array}{l}\mathrm{RFI} \geq 0.90(\text { good fit }) \\
0.80 \leq \mathrm{RFI} \leq 0.90(\text { good fit })\end{array}$ & 0.18 & Marginal \\
\hline $\mathrm{CN}$ & $\mathrm{CN} \geq 200$ & 49.77 & Good \\
\hline RMR & $\mathrm{RMR} \leq 0.05($ good fit $)$ & 0.096 & Relative \\
\hline GFI & $\begin{array}{l}\text { GFI } \geq 0.90(\text { good fit }) \\
0.80 \leq \mathrm{GFI} \leq 0.90(\text { good fit })\end{array}$ & 0.78 & Good \\
\hline AGFI & $\begin{array}{l}\text { AGFI } \geq 0.90(\operatorname{good} f i t) \\
0.80 \leq \mathrm{AGFI} \leq 0.90(\text { good fit })\end{array}$ & 0.74 & Good \\
\hline
\end{tabular}

Sumber: Data Penelitian, 2017 


\begin{tabular}{|c|c|c|c|}
\hline Variabel Laten dan Indikator & $\begin{array}{l}\text { Estimasi } \\
\text { Standar }\end{array}$ & $\begin{array}{l}\text { Standard } \\
\text { Error }\end{array}$ & $\begin{array}{l}\text { Nilai } \\
-t\end{array}$ \\
\hline \multicolumn{4}{|l|}{ Iklim Organisasi } \\
\hline $\begin{array}{l}\text { Kemampuan melaksanakan setiap kesepakatan organisasi dengan } \\
\text { tanggung jawab }\end{array}$ & 5.47 & 0.094 & 57.99 \\
\hline Kemampuan menerima perbedaan pendapat saat bekerja & 0.20 & 0.056 & 3.67 \\
\hline Penghargaan atas prestasi kerja & 0.021 & 0.037 & $(\mathbf{0 . 5 7})$ \\
\hline Pujian atas keberhasilan kerja pegawai & 0.56 & 0.14 & 3.97 \\
\hline Alur kerja antar divisi tidak jelas & 0.072 & 0.055 & (1.31) \\
\hline Imbalan memberikan kenyamanan dalam bekerja & 0.14 & 0.045 & 3.03 \\
\hline Kesempatan untuk berkembang sesuai dengan keahlian yang dimiliki & 0.21 & 0.057 & 3.66 \\
\hline Komunikasi dua arah dengan pegawai & 0.026 & 0.040 & $(0.66)$ \\
\hline \multicolumn{4}{|l|}{ Komunikasi Interpersonal } \\
\hline $\begin{array}{l}\text { Sikap positif atas masukan dari orang lain dalam hubungan formal dan } \\
\text { informal }\end{array}$ & 1.16 & 1.34 & 7.89 \\
\hline Hubungan dialogis antar pelaku komunikasi & 0.34 & 0.12 & 2.92 \\
\hline Memahami perasaan orang lain & 1.13 & 0.33 & 3.43 \\
\hline Dapat menempatkan diri pada posisi orang lain & 0.38 & 0.10 & 3.79 \\
\hline Tidak bersikap defensif & 0.38 & 0.11 & 3.39 \\
\hline Menyimak apa yang disampaikan orang lain & 0.29 & 0.092 & 3.19 \\
\hline Sikap yang objektif dalam menilai orang lain & 1.15 & 0.35 & 3.33 \\
\hline Terbuka untuk kerjasama dengan orang lain & 0.59 & 0.19 & 3.05 \\
\hline Tidak mendikte pembicaraan & 0.52 & 0.18 & 2.99 \\
\hline Menggunakan bahasa yang sama & 0.26 & 0.12 & 2.28 \\
\hline \multicolumn{4}{|l|}{ Komitmen Organisasi } \\
\hline Memiliki keterikatan emosional yang kuat dengan organisasi & 0.49 & 0.79 & 10.41 \\
\hline Menikmati keanggotaan dalam organisasi & 0.50 & 0.50 & $(\mathbf{1 . 0 0 )}$ \\
\hline Terlibat secara aktif dalam kegiatan organisasi & 1.00 & 0.80 & (1.25) \\
\hline $\begin{array}{l}\text { Memiliki keterikatan dengan organisasi berdasarkan pertimbangan } \\
\text { untung dan rugi }\end{array}$ & 0.081 & 0.16 & $(\mathbf{0 . 5 2})$ \\
\hline Memiliki keterikatan dengan organisasi berdasarkan kebutuhan pribadi & 0.22 & 0.20 & (1.12) \\
\hline Memiliki tanggung jawab moral secara pribadi terhadap organisasi & 0.51 & 0.68 & $(\mathbf{0 . 7 5 )}$ \\
\hline $\begin{array}{l}\text { Memiliki keterikatan dengan organisasi berdasarkan peraturan } \\
\text { organisasi }\end{array}$ & 0.38 & 0.29 & (1.32) \\
\hline \multicolumn{4}{|l|}{ Kepuasan Kerja } \\
\hline Mensiasati beban kerja yang berlebihan & 0.57 & 0.046 & 27.84 \\
\hline Menyikapi beban kerja yang terlalu sedikit & 0.62 & 0.078 & 7.92 \\
\hline Imbalan yang diterima sesuai dengan beban kerja yang ada & 0.63 & 0.21 & 2.99 \\
\hline Prestasi kerja akan menentukan jumlah imbalan yang diterima & 1.35 & 0.27 & 5.01 \\
\hline Promosi jabatan tidak dilakukan secara terbuka & 0.19 & 0.14 & (1.32) \\
\hline Promosi jabatan dilakukan sesuai prestasi kerja & 0.32 & 0.084 & 3.82 \\
\hline Membuka diri untuk menerima perbedaan pendapat & 0.40 & 0.18 & 2.28 \\
\hline Melakukan komunikasi yang harmonis dalam kerja & 0.24 & 0.11 & 2.23 \\
\hline Melakukan olahraga & 0.64 & 0.17 & 3.69 \\
\hline Melakukan silaturahmi sesama rekan kerja & 2.58 & 0.53 & 4.85 \\
\hline
\end{tabular}

Sumber: Data Penelitian, 2017 
model pengukuran (measurement model) dan pengujian model persamaan struktural (structural model). Setelah pengujian kecocokan model dan data secara keseluruhan, dilakukan pengujian model pengukuran untuk tiap variabel laten (analisis faktor). Pengujian ini dilakukan untuk mengetahui dan menguji sejauh mana butir butir yang diperkirakan dapat menjadi variabel terukur atau variabel manifest dapat dijadikan sebagai indikator dari variabel latennya. Pengujian model pengukuran ini didasarkan pada tiga jenis nilai untuk dijadikan dasar penentuan indikator yang baik, yaitu: (1) muatan faktor standar (standardized loading factors / estimasi standar) yang menunjukkan koefisien regresi dari setiap variabel terukur terhadap variabel latennya; (2) standar kesalahan (standard error) yang menunjukkan kecermatan dalam mengestimasi besarnya muatan. Makin besar nilai standar kesalahan, makin rendah ketepatan estimasi. Dengan kata lain, indikator tersebut kurang baik. (3) Nilai statistik uji t atau t hitung ( $t$-value) untuk menggambarkan sejauh mana kebermaknaan suatu variabel terukur (Wijayanto, 2008).

Lebih lanjut, bila nilai $t$ ( $t$ value) yang diperoleh lebih besar atau sama dengan $\geq 1.96$, yaitu nilai thitung muatan faktornya lebih besar dari nilai kritis t pada $\alpha=0.05$ atau $\geq 1.96$ untuk tingkat signifikansi 0.05 (Wijayanto, 2008), berarti variabel terukur tersebut bermakna, atau dapat dijadikan sebagai indikator yang baik terhadap konstruk atau variabel latennya. Apabila nilai t lebih kecil dari 1.96, maka berarti tidak bermakna sehingga tidak dapat dijadikan sebagai indikator yang baik.

Sementara itu, pengujian model struktural dalam penelitian ini dilakukan berdasarkan asumsi bahwa kepuasan kerja merupakan variabel yang dipengaruhi oleh iklim organisasi, komunikasi interpersonal, dan komitmen organisasi. Iklim organisasi memengaruhi komunikasi interpersonal dan komitmen organisasi. Komunikasi interpersonal dan komitmen organisasi saling memengaruhi. Tabel 3 menggambarkan hubungan antar variabel tersebut.

Dari serangkaian penelitian yang dilakukan terkait kepuasan kerja, para ahli membuktikan bahwa variabel iklim organisasi, komunikasi interpersonal maupun komitmen organisasi secara terpisah memiliki pengaruh terhadap kepuasan kerja. Memahami bahwa kepuasan kerja dapat dipengaruhi oleh berbagai variabel, maka peneliti mencoba untuk mengintegrasikan dan melihat pengaruh berbagai variabel tersebut terhadap kepuasan kerja dalam satu model penelitian. Berdasarkan kajian terdahulu, penelitian ini dilakukan untuk menguji model teoritik hubungan pengaruh variabel iklim

Tabel 3 Model Struktural - Hubungan Antar Variabel

\begin{tabular}{|c|c|c|c|c|c|}
\hline $\begin{array}{l}\text { Variabel Laten } \\
\text { Independen }\end{array}$ & & Variabel Laten Dependen & $\begin{array}{l}\text { Parameter } \\
y\end{array}$ & $\begin{array}{l}\text { Estimasi } \\
\text { Standar }\end{array}$ & Nilai t \\
\hline $\begin{array}{l}\text { Iklim } \\
\text { Organisasi }\end{array}$ & $\rightarrow$ & Komunikasi Interpersonal & $\gamma$ & 0.097 & $(1.05)$ \\
\hline $\begin{array}{l}\text { Iklim } \\
\text { Organisasi }\end{array}$ & $\longrightarrow$ & Komitmen Organisasi & $\gamma^{21}$ & 0.014 & $(0.67)$ \\
\hline $\begin{array}{l}\text { Iklim } \\
\text { Organisasi }\end{array}$ & $\rightarrow$ & Kepuasan Kerja & 31 & 0.088 & 5.21 \\
\hline $\begin{array}{l}\text { Komunikasi } \\
\text { Interpersonal }\end{array}$ & $\longrightarrow$ & Kepuasan Kerja & $\beta 31$ & 0.01 & 3.75 \\
\hline $\begin{array}{l}\text { Komunikasi } \\
\text { Interpersonal }\end{array}$ & $\rightarrow$ & Komitmen Organisasi & $\beta 21$ & 0.93 & 6.36 \\
\hline $\begin{array}{l}\text { Komitmen } \\
\text { Organisasi }\end{array}$ & $\rightarrow$ & Komunikasi Interpersonal & $\beta 12$ & 0.033 & $(0.074)$ \\
\hline $\begin{array}{l}\text { Komitmen } \\
\text { Organisasi }\end{array}$ & $\rightarrow$ & Kepuasan Kerja & $\beta 32$ & 0.25 & $(0.60)$ \\
\hline
\end{tabular}

Sumber: Data Penelitian, 2017 
organisasi, komunikasi interpersonal dan komitmen organisasi terhadap kepuasan kerja. Variabel komitmen organisasi merupakan variabel yang mewakili aspek psikologis, sedangkan variabel iklim organisasi dan komunikasi interpersonal mewakili aspek komunikasi.

Adapun jumlah responden dalam penelitian ini adalah sebanyak 100 pegawai tetap dan pegawai honorer kecamatan yang bekerja di kantor Kecamatan XYZ Kabupaten Bekasi, Provinsi Jawa Barat. Seluruh 100 orang karyawan itu terdiri atas pegawai laki-laki sebanyak 54 persen dan pegawai perempuan sejumlah 46 persen. Usia para pegawai negeri sipil itu adalah berkisar antara 20-40 tahun, sebanyak 74 persen, sedangkan yang berusia 40 tahun ke atas ada sebanyak 26 persen. Dari uraian data tersebut, maka semua pegawai negeri di kantor kecamatan itu adalah pekerja dalam usia produktif katagori dewasa muda. Dapat diartikan, para pegawai itu sedang berada dalam kondisi sehat, produktif dan energik untuk menghasilkan karya karya yang bernas.

Dari pengujian model ditemukan beberapa hal penting. Pertama, dari hasil uji struktural diketahui bahwa pengaruh variabel iklim organisasi (nilai t sebesar 5.21) dan komunikasi interpersonal (nilai $\mathrm{t}$ sebesar 3.75) terhadap kepuasan kerja adalah signifikan (nilai $\mathrm{t} \geq 1.96$ ). Bahwa secara terintegrasi hanya variabel iklim organisasi dan komunikasi interpersonal yang memiliki pengaruh terhadap kepuasan kerja.

Kedua, berdasarkan model teoritik yang diujikan diketahui bahwa variabel iklim organisasi memiliki pengaruh yang lebih kuat dibandingkan variabel komunikasi interpersonal terhadap kepuasan kerja (koefisien struktural 0,088). Adapun variabel komitmen organisasi tidak memiliki pengaruh yang signifikan terhadap kepuasan kerja (nilai t sebesar 0.60). Sementara itu, komunikasi interpersonal memilikipengaruhyangkuatterhadap komitmen organisasi (nilai t sebesar 6.36, koefisien struktural 0.93), dan sebaliknya komitmen organisasi tidak memiliki hubungan signifikan dengan variabel komunikasi interpersonal (nilai $\mathrm{t}$ sebesar 0.074) . Dari beberapa temuan yang relevan dengan permasalahan, tujuan dan signifikansi penelitian dapat didiskusikan beberapa hal untuk menjelaskan hasil penelitian yang ada.

Terkait dengan hasil uji model struktural, terbukti bahwa iklim organisasi memiliki pengaruh signifikan terhadap kepuasan kerja (nilai t sebesar 5.21, koefisien jalur 0.088). Hasil ini menguatkan hasil penelitian yang dilakukan (Castro dan Martin 2010); (Adeniji, 2011); dan (Djailani, Ibrahim, \& others, 2014) bahwa iklim organisasi yang terwakili oleh budaya organisasi berpengaruh positif dan signifikan terhadap kepuasan kerja. Lebih lanjut, antar variabel komunikasi interpersonal dan kepuasan kerja (nilai t sebesar 3.75, koefisien jalur 0.01) terdapat pengaruh yang signifikan.

Menurut Dance dan Larson, proses komunikasi interpersonal yang berlangsung secara efektif akan menggerakkan tiga fungsi komunikasi, yaitu linking function, mentation function, dan regulatory function yang merupakan pusat dari operasional organisasi. Manakala karyawan saling berkomunikasi (linking function) maka koordinasi kerja akan dapat dilakukan dan konflik dapat dihindarkan (mentation function). Dengan komunikasi, karyawan akan memahami peraturan kerja secara baik (regulatory functions). Dari konsep pemikiran Dance dan Larson terlihat bahwa komunikasi interpersonal dapat meningkatkan hubungan antar karyawan, mencegah timbulnya konflik dan menumbuhkan rasa kebersamaan dalam mencapai target perusahaan (Dance \& Larson, 1976).

Hasil penelitian memperlihatkan bahwa antara variabel komunikasi interpersonal dan komitmen organisasi (nilai t sebesar 6.36, koefisien jalur sebesar 0.93) terdapat hubungan signifikan. Secara teoretis, kebutuhan seseorang untuk tetap berada dalam suatu kelompok berpengaruh pada hubungan antara komunikasi dan komitmen organisasi. Semakin tinggi kebutuhan seseorang terhadap kelompok maka akan semakin kuat pengaruh komunikasi terhadap komitmen, dan sebaliknya.

Menyikapi pengaruh yang lemah dari variabel komitmen organisasi terhadap variabel kepuasan kerja (nilai t sebesar 0.60, koefisien jalur 0.25), peneliti berpendapat kondisi ini dikarenakan kondisi pegawai negeri sipil (PNS) yang puas atau tidak puas dengan pekerjaannya akan tetap bekerja di lingkungan pemerintahan sebab pegawai negeri merupakan pekerjaan yang menjadi dambaan banyak pencari kerja sehingga seseorang yang sudah diterima sebagai pegawai negeri tidak akan mau meninggalkan pekerjaan tersebut begitu saja. 
Sementara itu, hasil uji model struktural menunjukkan pengaruh yang lemah pada hubungan komitmen organisasi terhadap komunikasi interpersonal (nilai t sebesar 0.74, koefisien jalur 0.033). Peneliti berasumsi bahwa hal ini merupakan akibat dari kepesatan perkembangan teknologi. Yaitu, untuk menjaga komitmen terhadap organisasi, komunikasi dapat dilakukan menggunakan media elektronik dan tidak terbatas pada komunikasi tatap muka. Dengan bantuan peralatan teknologi komunikasi yang kini sangat canggih, maka berbagai pekerjaan yang ada dapat dikerjakan dari mana saja, di kantor maupun di luar kantor, sepanjang saluran internet tersedia dengan baik.

Di sisi lain, peneliti juga berasumsi bahwa lemahnya pengaruh variabel komitmen organisasi terhadap komunikasi interpersonal juga dikarenakan faktor budaya. Sebagaimana dipahami karyawan memiliki kecenderungan berorientasi pada budaya kolektivistik yang cenderung berorientasi pada tujuan kelompok. Yaitu, budaya yang lebih mengutamakan hubungan internal kelompok, dan lebih memperhatikan pertimbangan kelompok daripada pribadi.

Dalam penelitian ini juga diketahui bahwa variabel iklim organisasi tidak memiliki hubungan yang signifikan terhadap komunikasi interpersonal (nilai $\mathrm{t}$ sebesar 1.05, koefisien jalur 0.097) dan komitmen organisasi (nilai t sebesar 0.67, koefisien jalur 0.014). Dalam hal ini iklim organisasi membentuk budaya organisasi yang cenderung mengutamakan komunikasi kelompok dibandingkan dengan komunikasi interpersonal. Yaitu, keputusan kerap ditentukan oleh norma masyarakat yang bersifat interdependensi dengan mengutamakan keharmonisan hubungan dalam kelompok. Hal itu juga dicerminkan dengan pola kerja kantor kecamatan yang guyup dengan para pegawai saling mengenal satu sama lainnya, mengingat areal perkantoran yang tidak luas dan besar.

Lebih lanjut, hasil penelitian yang memperlihatkan tidak adanya pengaruh signifikan variabel iklim organisasi terhadap komitmen organisasi. Hal ini harus dipahami dalam konteks budaya kolektivistik. Yaitu, Iklim organisasi yang terbentuk berasal dari faktor komitmen individu dari para pelaku organisasi. Hal ini menyebabkan individu cenderung memiliki komitmen kuat pada norma yang terbentuk kelompok dibandingkan komitmen pada organisasi (Pace \& Faules, 2000).

\section{SIMPULAN}

Penelitian ini didasarkan pada titik tolak bahwa kepuasan kerja bisa dijelaskan tidak hanya oleh satu variabel saja, namun dapat dijelaskan secara holistik (gabungan dari berbagai variabel). Titik tolak atau asumsi ini didasari pada hasil penelusuran penelitian para ahli sebelumnya yang telah membuktikan bahwa kepuasan kerja bisa dipengaruhi oleh lebih dari satu variabel.

Berdasarkan titik tolak ini, peneliti melihat celah pemikiran untuk meneliti integrasi pengaruh variabel iklim organisasi, komunikasi interpersonal dan komitmen organisasi terhadap kepuasan kerja dalam satu model penelitian. Untuk mendapatkan gambaran yang lebih menyeluruh tentang pengaruh dari masingmasing variabel terhadap kepuasan kerja dilakukan analisis hubungan kausal dengan menggunakan program Lisrel 8.80.

Hasil penelitian di kantor Kecamatan XYZ, Kabupaten Bekasi, Provinsi Jawa Barat, menunjukkan bahwa model integrasi variabel iklim organisasi, komunikasi interpersonal dan komitmen organisasi terhadap kepuasan kerja tidak memiliki pengaruh yang signifikan. Hasil ini sekaligus memperlihatkan bahwa hanya tiga dari tujuh hipotesa penelitian terbukti.

Secara umum, hasil penelitian membuktikan bahwa kepuasan kerja karyawan yang bekerja di Kecamatan XYZ bisa dipengaruhi variabel iklim organisasi dan variabel komunikasi interpersonal. Sementara itu, variabel komitmen organisasi tidak memiliki pengaruh signifikan terhadap kepuasan kerja para karyawan yang bekerja di Kecamatan XYZ tersebut.

Adapun saran untuk penelitian terkait model integrasi pengaruh variabel iklim organisasi, komunikasi interpersonal dan komitmen organisasi terhadap kepuasan kerja, dapat dilakukan pada lingkup kerja organisasi swasta. Hal ini disarankan mengingat budaya organisasi organisasi pemerintah dengan petugas berstatus pegawai negeri sipil (aparatur sipil negara) dan organisasi swasta memiliki budaya kerja yang berbeda.

Lebih lanjut, berdasarkan hasil penelitian ini, disarankan untuk lebih meningkatkan komunikasi antarkaryawan maupun komunikasi karyawan dengan pimpinannya di kantor 
kecamatan itu dalam upaya peningkatan kepuasan kerja di lingkungan kantor Kecamatan XYZ, Kabupaten Bekasi, Provinsi Jawa Barat.

Para peneliti menyampaikan ucapan terimakasih kepada Rektor Universitas Mercu Buana - Jakarta, Prof. Dr. Ngadino Surip yang telah memfasilitasi penelitian ini hingga bisa berjalan sesuai rencana. Ucapan terimakasih juga disampaikan kepada para kolega di Lembaga Penelitian dan Pengabdian kepada Masyarakat (LPPM) Universitas Mercu Buana, serta kolega peneliti di Program Magister Ilmu Komunikasi Universitas Mercu Buana yang banyak meluangkan waktu untuk mendiskusikan penelitian ini. Ucapan terimakasih serupa disampaikan juga kepada para kolega di Lembaga Penelitian dan Pengabdian kepada Masyarakat (LPPM) Universitas Prof. Dr. Moestopo (Beragama) Jakarta yang telah mendukung terlaksananya penelitian kolaborasi antardua universitas ini.

\section{DAFTAR PUSTAKA}

Adeniji, A. A. (2011). Organizational climate as a predictor of employee job satisfaction: evidence from covenant university. Business Intelligence Journal, 4(1), 151166.

Badan Pusat Statistik (BPS). (2017). Jumlah pegawai negeri sipil menurut jenis kepegawaian dan jenis kelamin,desember 2013 dan desember 2016. Diakses dari https://www.bps. go.id/statictable/2015/09/08/1798/ jumlah-pegawai-negeri-sipil-menurutjenis-kepegawaian-dan-jenis-kelamindesember-2013-dan-desember-2016.html

Castro, M. L., \& Martins, N. (2010). The relationship between organisational climate and employee satisfaction in a south african information and technology organization. SA Journal of Industrial Psychology, 36(1), $1-9$.

Diasmoro, O. (2016). Hubungan komunikasi interpersonal dengan kepuasan kerja karyawan dewasa awal bagian produksi pt. Gangsar tulungagung. University of Muhammadiyah Malang.

Djailani, A. R., Ibrahim, S., \& others. (2014). Pengaruh iklim organisasi dan kepusasan kerja terhadap kinerja guru. Jurnal Administrasi Pendidikan: Program
Pascasarjana Unsyiah, 2(2).

Gusliza, N. (2013). Hubungan komunikasi interpersonal dengan kepuasan kerja pegawai dinas pendidikan pemuda dan olahraga kota bukittinggi. Jurnal Bahana Manajemen Pendidikan, 1(1).

Harivarman, D. (2017). Hambatan komunikasi internal di organisasi pemerintahan. Jurnal ASPIKOM-Jurnal Ilmu Komunikasi, 3(3), 508-519.

Irawan, D. \& Venus, A. (2016). Pengaruh iklim komunikasi organisasi terhadap kinerja pegawai kantor keluarga berencana jakarta barat. Jurnal Kajian Komunikasi, 4(2), 122-132.

Natarajan, N. K. (2011). Relationship of organizational commitment with job satisfaction. Indian Journal of Commerce \& Management Studies, 2(1), 118-122.

Pace, R. W. \& Faules, D. F. (2000). Komunikasi organisasi: strategi meningkatkan kinerja perusahaan. Editor: Deddy Mulyana. Bandung: Remaja Rosdakarya.

Peraturan Menteri Dalam Negeri. (2017). Peraturan menteri dalam negeri no. 137 tahun 2017 tentang kode, dan data wilayah administrasi pemerintahan per provinsi,kabupaten/kota dan kecamatan seluruh indonesia. Diakses dari https:// www.kemendagri.go.id/pages/detail/108permendagri-no137-tahun-2017.

Peraturan Pemerintah. (2008). Peraturan pemerintah republik indonesia nomor 19 tahun 2008 tentang kecamatan. Diakses dari http://ditjenpp.kemenkumham.go.id/ arsip/ln/2008/pp19-2008.pdf

Perloff, R. M. (2017). The dynamics of persuasion: communication and attitudes in the 21st century. The Dynamics of Persuasion: Communication and Attitudes in the Twenty-First Century, 1-628. https:// doi.org/10.4324/9781315657714

Pratiwi, S. R., Dida, S., \& Sjafirah, N. A. (2018). Strategi komunikasi dalam membangun awareness wisata halal di kota bandung. Jurnal Kajian Komunikasi, 6(1), 78-90.

Putri, Y. A., \& Destiwati, R. (2017). Pengaruh kualitas pelayanan pusat bahasa universitas telkom terhadap kepuasan pengguna layanan. Jurnal Kajian Komunikasi, 5(1), 102-110.

Qofiki, M. N., Sunuharjo, B. S., \& Ruhana, 
I. (2016). Pengaruh kepuasan kerja dan komitmen organisasional terhadap kinerja karyawan (studi pada pt. Telekomunikasi indonesia, tbk witel jatim selatan, malang). Jurnal Administrasi Bisnis, 34(1), 38-46.

Rogers,E.M.(1994).A historyof communication study: a biographical approach. New York: The Free Press.

Rosilawati, Y. (2014). Employee branding sebagai strategi komunikasi organisasi untuk mengkomunikasikan citra merek. Jurnal Ilmu Komunikasi, 6(3).
Sanjaya, A., Alunaza, H. (2017). Pemeliharaan hubungan dan komunikasi organisasi via media siber. Jurnal Ilmu Komunikasi, 14(2), 239-258.

Susanty, E. (2012). Pengaruh iklim organisasi terhadap kepuasan kerja dan komitmen karyawan pada universitas terbuka. Jurnal Organisasi dan Manajemen, 8(2), 121134.

Wijayanto, S. H. (2008). Structural equation modeling dengan lisrel 8.8. Yogyakarta: Graha Ilmu. 